\title{
PERAN DAN STRATEGI PENGEMBANGAN SUBSEKTOR PETERNAKAN DALAM PEMBANGUNAN KABUPATEN AGAM SUMATERA BARAT
}

\author{
Yulia ${ }^{1}$, Lukman M. Baga ${ }^{2}$, dan Netti Tinaprilla ${ }^{2}$ \\ 1)Mahasiswa Pascasarjana Magister Sains Agribisnis, Departemen Agribisnis \\ Fakultas Ekonomi dan Manajemen, Institut Pertanian Bogor \\ 2)Staf Pengajar Departemen Agribisnis, Fakultas Ekonomi dan Manajemen, Institut Pertanian Bogor \\ e-mail : 1)a_yulia@rocketmail.com
}

\begin{abstract}
Agam District Government has the goal of improving economic growth rate of 5.94 percent in 2011 to 7.98 percent in 2017. However, the constraints experienced by the development of the animal husbandry sector is a decrease in the growth rate of the animal husbandry sector and the contribution to the GDP, it is necessary for the development of the animal husbandry subsector in Agam by taking into account various aspects. This study aims to analyze the potential and role of formulating priority strategies of alternative development strategy animal husbandry subsector. Results of the analysis of the animal husbandry subsector $L Q$ is a commodity basis. The shift results proportional growth 10.72 percent negative growth. Region share growth of 2.33 percent. The results obtained from the alternative strategies SWOT matrix were analyzed using QSPM. development and coaching each region based on the existing potential (6.278), increasing the promotion and development of human resources breeder (5.773), to build and develop patterns of cooperation and mutual benefit (5.618), examination of animal health and disease prevention (5.406), implementation and development appropriate technology (5.330) and optimization in securing local resources (4.982). Selected strategic alternatives of highest appeal total development strategy as well as coaching is done each region based on the existing potential (6.278), then the suggestions can be made to the Government Agam namely increasing the number of livestock extension workers and attract investors to develop the livestock subsector in Agam District.
\end{abstract}

Keywords: animal husbandry subsector, location quotient, shift share, SWOT, QSPM

\section{PENDAHULUAN}

Pada era otonomi daerah saat sekarang ini, daerah diberikan kewenangan dan peluang yang luas bagi pengembangan potensi ekonomi, sosial, politik dn budaya. Salah satu bentuk peluang itu adalah perlunya penajaman orientasi pembangunan yang berbasis pada potensi daerah. Menurut Bahar, 2006 menyatakan bahwa masingmasing daerah didorong tidak saja untuk lebih mampu mengambil peran dan prakarsa dalam perencanaan pembangunan, tetapi juga untuk lebih jeli mengeksplorasi dan mengeksploitasi sumber daya yang tujuannya untuk mensejahterakan rakyat setempat.

Pada tahun 1999 konsep otonomi daerah dikeluarkan melalui UU No. 22/1999. Otonomi daerah yang tertuang pada Pasal 1 UU No. 22/1999 adalah daerah otonom memiliki kewenangan mengatur dan mengorganisir kepentingan masyarakat setempat menurut prakarsa sendiri berdasarkan aspirasi masyarakat sesuai dengan peraturan dan perundang-undangan.

Terkait dengan pemanfaatan sumber daya dan potensi daerah sektor pertanian memiliki akar pada sumberdaya domestik. Sekarang mulai timbul kesadaran bahwa pertanian dalam suatu sistem agribisnis merupakan sektor tangguh yang mampu bertahan dalam kondisi krisis. Pertanian juga merupakan sumber mata pencaharian utama penduduk, sehingga dapat dijadikan penggerak dalam meningkatkan pendapatan masyarakat, menciptakan kesempatan kerja dan berusaha. Secara keseluruhan peran pertanian dalam pembangunan dapat mengurangi tingkat kemiskinan dalam suatu 
wilayah apalagi sektor-sektor pertanian yang dijalankan seefektif mungkin (Diao et al 2010).

Salah satu sektor pertanian yang mengalami permasalahan adalah sub sektor peternakan yang masih kita jumpai, dimana sub sektor peternakan masih mengalami kondisi defisit dalam neraca perdagangannya. Sumber defisit neraca perdagangan terbesar adalah impor susu, ternak sapi dan daging sapi yang jumlahnya cukup besar (Kementan 2013). Pertumbuhan subsektor peternakan yang masih dijumpai beberapa permasalahan diantaranya pada industri unggas penyediaan pakan masih tergantung impor. Pada industri ruminansia besar, menghandalkan usaha peternakan rakyat tidak mampu memenuhi permintaan yang terus meningkat, dan industri pakannya belum diusahakan dengan baik. Terbatasnya infrastruktur dan perdagangan ternak hidup tanpa kendali berpeluang penyebaran penyakit dan tidak terjaminnya kualitas dan keamanan produk.

Sedangkan dari sisi konsumsi, terjadi senjang penawaran dan permintaan, khususnya pada daging sapi sehingga harus dipenuhi dari impor. Di sisi lain, kapasitas produksi ayam ras masih mampu ditingkatkan lagi, hanya permintaannya sangat tergantung pada daya beli konsumen, kualitas gizi dan keamanan produk. Semuanya itu merupakan peluang yang harus dimanfaatkan (Ilham, 2007). Untuk mengatasi permasalahan diperlukan strategi pengem- bangan dalam bidang pembangunan yang fokus pada sasaran yang tepat.

Salah satu Kabupaten yang ada di Provinsi Sumatera Barat yang memiliki potensi besar dalam sektor pertanian umumnya dan subsektor peternakan khususnya yaitu Kabupaten Agam dalam mengimplementasikan otonomi daerah berusaha untuk memanfaatkan potensi yang dimilikinya. Potensi yang dimiliki oleh Kabupaten Agam pada subsektor peternakan diharapkan mampu meningkatkan Pendapatan Daerah Regional Bruto (PDRB) yang menjadi salah satu indikator peningkatan kesejahteraan masyarakat yang merupakan suatu komponen yang sangat penting dalam kemajuan suatu daerah. Pemerintah Kabupaten Agam juga mempunyai sasaran untuk meningkatkan laju pertumbuhan ekonomi dari 5,94 persen pada tahun 2011 menjadi 7,98 persen pada tahun 2017.

Namun kendala yang dialami dalam pengembangan subsektor peternakan adalah penurunan laju pertumbuhan sektor peternakan dan kontribusi yang disumbangkan terhadap PDRB seperti terlihat pada Tabel 1 dan 2. Sektor pertanian merupakan unggulan Kabupaten Agam menjadi penyumbang terbesar dalam PDRB Kabupaten Agam yaitu mencapai 39,31 persen pada tahun 2013 terhadap total PDRB Kabupaten Agam walaupun mengalami penurunan pada tahun yang sama tapi tidak begitu signifikan seperti terlihat pada pada Tabel 1 .

Tabel 1. Persentase Distribusi Sektor Pertanian Terhadap PDRB Kabupaten Agam Tahun 2009 - 2013 Atas Dasar Harga Konstan 2000

\begin{tabular}{|l|r|r|r|r|r|}
\hline \multicolumn{1}{|c|}{ Lapangan usaha } & $\mathbf{2 0 0 9}$ & $\mathbf{2 0 1 0}$ & $\mathbf{2 0 1 1}$ & $\mathbf{2 0 1 2}$ & $\mathbf{2 0 1 3}$ \\
\hline Sektor pertanian & 36,43 & 37,88 & 38,49 & 39,72 & 39,31 \\
\hline - Tanaman pangan \& hortikultura & 19,01 & 19,68 & 20,51 & 22,83 & 23,11 \\
\hline - Tanaman perkebunan & 11,18 & 12,12 & 11,90 & 10,86 & 10,42 \\
\hline - Peternakan \& hasil-hasilnya & 3,89 & 3,73 & 3,70 & 3,68 & 2,92 \\
\hline - Kehutanan & 0,64 & 0,62 & 0,61 & 0,59 & 0,66 \\
\hline - Perikanan & 1,71 & 1,73 & 1,75 & 1,76 & 2,20 \\
\hline Sumber : BPS Kabupaten Agam, 2014 & & & & &
\end{tabular}


Tabel 2. Persentase Laju Pertumbuhan PDRB Sektor Pertanian Tahun 2009 - 2013 Atas Dasar Harga Konstan 2000

Sektor pertanian

Lapangan usaha

- Tanaman pangan \& hortikultura

- Tanaman perkebunan

- Peternakan \& hasil-hasilnya

- Kehutanan

- Perikanan

Sumber : BPS Kabupaten Agam, 2014

Apabila dilihat dari data selama 5 tahun terakhir ini (2009-2013) subsektor peternakan kabupaten agam mengalami penurunan laju pertumbuhan dibandingkan subsektor lainnya. Laju pertumbuhan subsektor peternakan menjadi 3,11 persen pada tahun 2013, dari yang sebelumnya 4,65 persen pada tahun 2009. Melihat fenomena yang terjadi selama 5 tahun (2009-2013) ini yaitu penurunan laju pertumbuhan subsektor peternakan terhadap PDRB sektor pertanian untuk itu perlu dilakukan pengembangan subsektor peternakan di Kabupaten Agam dengan memperhatikan berbagai aspek yaitu potensi sub sektor peternakan dan peranan peternakan yang dimiliki Kabupaten Agam. Melihat dari kondisi dan permasalahan juga latar belakang di atas maka rumusan masalah yang harus dilakukan analisis potensi dan peran subsektor peternakan terhadap pembangunan ekonomi dan bagaimana rumusan strategi prioritas dari alternatif strategi pengembangan subsektor peternakan dalam rangka meningkatkan peran subsektor peternakan di Kabupaten Agam Sumatera Barat.

\section{KERANGKA PEMIKIRAN TEORITIS}

\section{KONSEP PERTUMBUHAN DAN PEMBANGUNAN EKONOMI}

Salah satu teori yang ada tentang pertumbuhan ekonomi menyebutkan bahwa tanah memiliki peran yang penting dalam pertumbuhan ekonomi. Hal ini dikarenakan tanah dan lahan yang semakin langka dan kemudian membuat harga tanah yang ada menjadi mahal sehingga menyebabkan harga

\begin{tabular}{|r|r|r|r|r|}
\hline $\mathbf{2 0 0 9}$ & $\mathbf{2 0 1 0}$ & $\mathbf{2 0 1 1}$ & $\mathbf{2 0 1 2}$ & $\mathbf{2 0 1 3}$ \\
\hline 5,45 & 4,10 & 4,83 & 6,92 & 5,77 \\
\hline 5,91 & 3,16 & 5,23 & 7,29 & 6,69 \\
\hline $\mathbf{5} 25$ & 5,61 & 3,92 & 6,51 & 6,10 \\
\hline $\mathbf{4} 65$ & 4,50 & 4,45 & 4,12 & 3,11 \\
\hline $\mathbf{1 5}$ & 2,16 & 5,46 & 3,13 & 3,50 \\
\hline & 3,09 & 7,43 & 8,94 & 9,40 \\
\hline
\end{tabular}

sewa yang ada juga meningkat. Sedangkan teori-teori yang berkaitan dengan pembangunan ekonomi dapat digolongkan menjadi 5 golongan besar yaitu aliran Klasik, Karl Marx, Shumpeter, Neo Klasik, serta Post Keynesian. Teori-teori ini mengemukakan sebab-sebab pertumbuhan pendapatan nasional dan proses pertumbuhannya.

Pembangunan Ekonomi merupakan proses perpaduan antara pertumbuhan penduduk dan kemajuan teknologi dan pembangunan ekonomi adalah usaha-usaha untuk meningkatkan taraf hidup suatu bangsa yang seringkali diukur dengan tinggi rendahnya pendapatan riil perkapita. Pembangunan ekonomi merupakan suatu proses yang menyebabkan pendapatan perkapita penduduk suatu masyarakat meningkat dalam jangka panjang.

Pertumbuhan ekonomi dapat dijadikan salah satu indikator keberhasilan pembangunan ekonomi suatu wilayah. Terjadinya pembangunan ekonomi ditandai dengan bertambahnya laju pertumbuhan ekonomi suatu wilayah yang lebih besar daripada laju pertumbuhan penduduknya. Sebagai akibatnya, ketimpangan distribusi pendapatan semakin kecil, kemiskinan semakin berkurang, sehingga kesejahteraan penduduk akan meningkat.

\section{Model Analisis Shift Share}

Analisis ini merupakan metode untuk melihat aktifitas ekonomi di suatu wilayah dengan menggunakan berbagai data. Perubahan indikator kegiatan ekonomi dilihat dari dua titik waktu, yaitu tahun akhir analisis dan tahun dasar analisis. Secara skematik analisis shift share disajikan pada Gambar 1. 


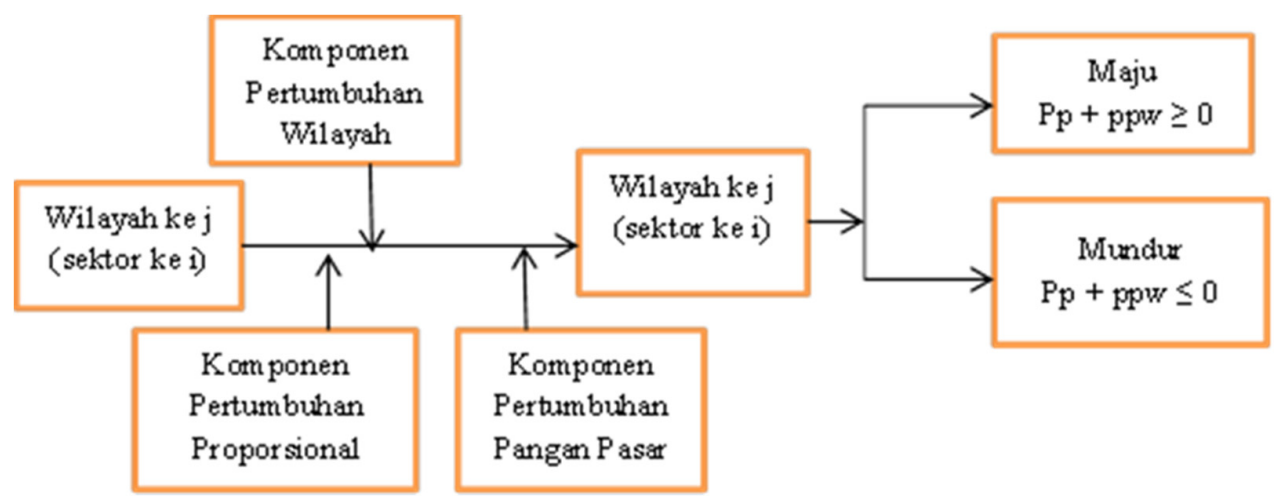

Gambar 1. Model Analisis Shift Share

Sumber : Budiharsono, 2001

Pertumbuhan sektor perekonomian pada suatu wilayah dipengaruhi beberapa komponen, yaitu : komponen pertumbuhan regional (regional growth component) disingkat PN, Komponen pertumbuhan proporsional (proportional or industrial mix growht component) disingkat PP dan komponen pangsa wilayah (regional share growth component) disingkat PPW. Dari ketiga komponen tersebut diidentifikasi pertumbuhan suatu sektor perekonomian, apakah pertumbuhan cepat atau lambat. Apabila $\mathrm{PP}+\mathrm{PPW} \geq 0$, maka pertumbuhan sektor perekonomian termasuk ke dalam kelompok progresif (maju). Tetapi apabila PP $+\mathrm{PPW} \leq 0$ berarti sektor perekonomian tersebut memiliki pertumbuhan yang lambat.

\section{KONSEP FORMULASI STRATEGI}

Menurut David (2006) formula strategi adalah menentukan aktivitas-aktivitas yang berhubungan dengan pencapaian tujuan.

\section{Analisis Lingkungan Eksternal}

Analisis lingkungan eksternal terdiri dari variabel-variabel (peluang dan ancaman) yang berada di luar organisasi dan tidak secara khusus ada dalam pengendalian jangka pendek dalam manajemen puncak. Tujuan analisis lingkungan eksternal adalah untuk mengembangkan daftar terbatas peluang yang dapat dimanfaatkan perusahaan dan ancaman yang harus dihindari.

\section{Analisis Lingkungan Internal}

Analisis lingkungan internal terdiri dari variabel-variabel (kekuatan dan kelemahan) yang ada di dalam organisasi tetapi biasanya tidak dalam pengendalian jangka pendek dari manajemen puncak. Lingkungan internal terdiri dari komponen-komponen atau variabel lingkungan yang berasal atau berada di dalam organisasi/perusahaan atau berada di dalam jangkauan intervensi mereka.

\section{Matriks SWOT}

Matrik SWOT merupakan alat pencocokan yang penting membantu manajer mengembangkan empat tipe strategi, yaitu (1) strategi SO (Strenghts- Opportunity) yaitu menggunakan seluruh kekuatan yang dimiliki untuk merebut dan memanfaatkan peluang yang ada; (2) strategi WO (WeaknessOpportunity) bertujuan untuk pemanfaatan peluang yang ada untuk mengatasi kelemahan yang ada; (3) strategi ST (Strenghts-threats) yaitu menggunakan kekuatan yang dimiliki untuk menghindari dampak ancaman yang ada; (4) strategi WT (Weaknessthreats) merupakan taktik defensif yang diarahkan untuk meminimalkan kelemahan yang ada dan menghindari ancaman eksternal.

\section{Matriks QSPM}

QSPM (Quantitative Strategic Planning Matrix) merupakan alat yang memungkinkan ahli strategi untuk mengevaluasi strategi 
alternatif secara objektif berdasarkan pada faktor-faktor kritis untuk sukses eksternal dan internal yang dikenali sebelumnya, serta memerlukan penilaian intuitif yang baik atau tepat. Kegunaan QSPM adalah untuk menetapkan daya tarik relatif dari tindakan alternatif yang layak dan memutuskan strategi mana yang terbaik atau tepat.

\section{METODE PENELITIAN}

Penelitian ini dilakukan di Kabupaten Agam Propinsi Sumatera Barat dari bulan Desember 2014 sampai Maret 2015. Pemilihan daerah dilakukan dengan sengaja (purposive) dengan pertimbangan bahwa sektor pertanian umumnya dan sektor peternakan khususnya merupakan ciri dominan perekonomian daerah tersebut, dimana kondisi geografis dan sumberdaya alamnya mendukung kegiatan sektor pertanian dan peternakan.

Jenis data yang digunakan atau dikumpulkan dalam penelitian ini adalah data primer dan data sekunder. Data primer diperoleh dari wawancara langsung dengan pihak-pihak atau dinas yang terkait langsung dengan kebijakan dalam pembangunan peternakan. Data sekunder diperoleh dari berbagai literatur. Data sekunder yang utama berasal dari BPS yakni data series antara tahun 2009 sampai 2013. Sumber-sumber lain diperoleh dari instansi-instansi terkait, seperti Dinas Peternakan, Badan Perencanaan Pembangunan Daerah dan Dinas Pertanian atau instansi dan lembaga lainnya terkait dengan tujuan penelitian dan juga literatur jurnal nasional dan internasional.

Pengambilan responden untuk penentuan kekuatan eksternal dan internal, analisis SWOT, dan analisis QSPM dilakukan dengan metode Purposive Sampling. Menurut David (2006) dalam analisis ini untuk menentukan responden, tidak ada jumlah minimal yang diperlukan, sepanjang responden yang dipilih merupakan ahli di bidangnya. Responden dengan sengaja dipilih sebanyak 5 orang (karena penelitian ini tidak uji statistik). Responden adalah orang yang dianggap ahli mengenal betul dinamika perkembangan peternakan di Kabupaten Agam. Responden tersebut menggunakan kriteria Marimin (2004). Adapun responden yang akan dipilih kekuatan eksternal adalah sebagai berikut : 1 . Kabid Bina Program Dinas Pertanian Tanaman Pangan dan Hortikultura, 2. Bidang Perencanaan Perekonomian Badan Perencanaan Daerah, Dan responden kekuatan internal yang akan dipilih sebagai berikut : 1 . Kasi Bina Mutu Penyuluhan Peternakan, 2. Kasi Perencanaan dan Pengembangan Peternakan/produksi peternakan 3. Pelaksana Bina Usaha Peternakan.

\section{ANALISIS DATA}

Penelitian ini menggunakan metode deskriptif kuantitatif dan kualitatif. Pemakaian metode deskriptif bertujuan untuk menggambarkan kondisi dan keragaan pembangunan khususnya sektor peternakan yaitu keadaan umum wilayah potensi, wilayah keadaan sosial, ekonomi dan lain-lain yang berkaitan dengan tujuan penelitian. Analisis LQ untuk mengetahui basis peternakan di Kabupaten Agam. Analisis shift share untuk mengetahui pertumbuhan subsektor peternakan.

\section{Location Quotient (LQ)}

Metode LQ adalah perbandingan antar pangsa relatif pendapatan sektor tertentu pada tingkat wilayah terhadap pendapatan total wilayah dengan pangsa relatif pendapatan sektor tertentu terhadap pada tingkat nasional terhadap pendapatan nasional (Budiharsono, 2001).

Menurut Arsyad, dalam Basuki Tri A, Gayatri U (2009) dalam mengidentifikasi komoditi basis dan bukan komoditi basis pertanian, penggunaan LQ adalah sebagai berikut :

$$
\mathrm{LQ}=(\mathrm{Si} / \mathrm{Sj}) /(\mathrm{Ni} / \mathrm{Nj})
$$

dimana:

$\mathrm{LQ}=$ Besarnya kuosien lokasi subsektor peternakan di Kabupaten Agam termasuk kecamatan di wilayah Agam 
$\mathrm{Si}=$ Jumlah PDRB subsektor peternakan pada tingkat kecamatan/kabupaten

$\mathrm{Sj}=$ Jumlah total PDRB disetiap kecamatan/kabupaten

$\mathrm{Ni}=$ Jumlah PDRB subsektor peternakan pada tingkat kabupaten/provinsi

$\mathrm{Nj}=$ Jumlah total PDRB pada tingkat kabupaten/provinsi

Jika LQ > = 1, maka sektor tersebut termasuk sektor basis artinya sektor tersebut lebih berperan bagi perekonomian di suatu wilayah dibandingkan dengan wilayah lainnya.

\section{Surplus pendapatan}

$$
\mathrm{SP}=[(\mathrm{Si} / \mathrm{Sj})-(\mathrm{Ni} / \mathrm{Nj})]^{*} \mathrm{Si}
$$

dimana :

$\mathrm{Si}=$ Jumlah PDRB subsektor peternakan pada tingkat kecamatan/Kabupaten Agam

$\mathrm{Sj}=$ Jumlah total PDRB disetiap kecamatan/kabupaten

$\mathrm{Ni}=$ Jumlah PDRB Subsektor peternakan pada tingkat Kabupaten Agam atau Propinsi Sumatera Barat

$\mathrm{Nj}=$ Jumlah total PDRB pada tingkat Kabupaten Agam atau Propinsi Sumatera Barat

Jika surplus subsektor peternakan bernilai positif maka komoditi ini dapat memenuhi kebutuhan masyarakat. Sebaliknya jika surplus komoditi ini negatif maka tidak dapat memenuhi kebutuhan masyarakat, Budiharsono (2001).

\section{Kousien Lokalisasi (Loi)}

Digunakan untuk mengetahui penyebaran kegiatan peternakan di suatu daerah sehingga diketahui tingkat aglomerasinya (Budiharsono, 2001).

$$
\text { Loi }=(\mathrm{Si} / \mathrm{Sj})-(\mathrm{Ni} / \mathrm{Nj})
$$

dimana :

$\mathrm{Si}=$ Jumlah PDRB subsektor peternakan pada tingkat kecamatan/Kabupaten Agam
$\mathrm{Sj}=$ Jumlah total PDRB disetiap kecamatan/kabupaten

$\mathrm{Ni}=$ Jumlah PDRB Subsektor peternakan pada tingkat Kabupaten Agam atau Propinsi Sumatera Barat

$\mathrm{Nj}=$ Jumlah total PDRB pada tingkat Kabupaten Agam atau Propinsi Sumatera Barat

Bila nilai kousien lokalisasi lebih dari satu maka produksi suatu komoditi lebih memusat dan beraglomerasi pada satu wilayah. Sedangkan nilai kuosien lokalisasi kurang dari satu maka komoditi tersebut lebih bersifat menyebar.

\section{Analisis Shift Share}

Menurut Budiharsono (2001) analisis shift share digunakan untuk melihat perubahan PDRB yang terjadi pada dua titik waktu. Tahun analisis yang digunakan adalah tahun 2009 sampai dengan tahun 2013. Perubahan tersebut dapat dinyatakan sebagai berikut :

$\Delta Y i j=Y^{\prime} i j-Y i j$

\section{Analisis Komponen Pertumbuhan Wilayah}

Menurut Budiharsono (2001) Pertumbuhan sektor-sektor perekonomian suatu wilayah dipengaruhi oleh tiga komponen yaitu Pertumbuhan Nasional (PN), Pertumbuhan Proporsional (PP), dan Pertumbuhan Pangsa Wilayah (PPW). Ketiga Komponen tersebut dapat dirumuskan sebagai berikut:

Pnij $=(R a) Y i j$

Ppij $=(R i-R a) Y i j$

$P P W i j=(r i-R i) Y i j$

dimana :

$\mathrm{Ra}=\left(\mathrm{Y}^{\prime} . .-\mathrm{Y} ..\right) / \mathrm{Y}$..

$\mathrm{Ri}=\left(\mathrm{Y}^{\prime} \mathrm{i} .-\mathrm{Yi}\right) / \mathrm{Yi}$.

ri $=\left(Y^{\prime} i j-Y i j\right) / Y i j$

$Y^{\prime}=$ PDRB Propinsi Sumatera Barat pada tahun 2013 
Y.. = PDRB Propinsi Sumatera Barat pada tahun 2009

$Y^{\prime} i=$ PDRB Propinsi Sumatera Barat dari sektor i pada tahun 2013

Yi. $=$ PDRB Propinsi Sumatera Barat dari sektor i pada tahun 2009

$Y^{\prime} \mathrm{ij}=$ PDRB Kabupaten Agam sektor i pada wilayah ke j 2013

$Y i j=$ PDRB Kabupaten Agam sektor i pada wilayah ke j 2009

$\Delta Y i j=P n i j+P p i j+P P W i j$.

Apabila persamaan (1), (2), (3), dan (4) disubtitusikan ke persamaan (5) maka didapat:

$Y^{\prime} i j-Y i j=(R a) Y i j+(R i-R a) Y i j+(r i-R i) Y i j . .(6)$

Apabila Ppij < 0, menunjukkan bahwa sektor i pada wilayah ke j laju pertumbuhannya melambat, sedangkan apabila Ppij > 0 menunjukkan bahwa sektor i pada wilayah laju ke $\mathrm{j}$ laju pertumbuhannya cepat. Apabila PPW <0, sektor i tidak dapat bersaing dengan baik bila dibandingkan dengan wilayah lainnya, sedangkan apabila PPW $>0$, maka wilayah ke $\mathrm{j}$ mempunyai daya saing yang baik untuk perkembangan sektor i bila dibandingkan dengan wilayah lainnya.

Cara Efektif untuk mengevaluasi pertumbuhan produksi (PDRB) subsektor Peternakan ataupun sektor lain pada kurun waktu 2009-2013 adalah dengan cara mengekspresikan persen perubahan kom- ponen pertumbuhan proporsional (PP) dan pertumbuhan pangsa wilayah (PPW). Sumbu PP sebagai absis dan PPW sebagai ordinat (Gambar 2).

Profil pertumbuhan hasil analisis shift share dibagi menjadi 4 kuadran yaitu:

a. Kuadran I menunjukkan bahwa PP dan PPW bernilai positif. Hal ini berarti sektorsektor di wilayah tersebut pertumbuhannya cepat demikian juga daya saing wilayah untuk sektor-sektor tersebut baik apabila dibandingkan dengan wilayahwilayah lainnya. Hal ini juga menunjukkan bahwa pergesaran bersih bernilai positif yang berarti sektor-sektor tersebut merupakan wilayah progresif.

b. Kuadran II menunjukkan bahwa sektorsektor ekonomi yang berada di wilayah yang pertumbuhannya cepat, tetapi daya saing daya sektor tersebut tidak baik dibandingkan sektor lain.

c. Kuadran III menunjukkan bahwa sektorsektor ekonomi pada wilayah tertentu mengalami pertumbuhan lambat dan daya saing yang rendah. Hal ini juga menunjukkan bahwa semua sektor yang berada di kuadran III nilai pergesesaran bersihnya negatif yang berarti sektorsektor tersebut merupakan wilayah lamban.

d. Kuadran IV menunjukkan sektor-sektor yang berada pada wilayah tertentu mengalami pertumbuhan negatif/lambat, tetapi memiliki daya saing yang baik dibandingkan dengan sektor-sektor lain.

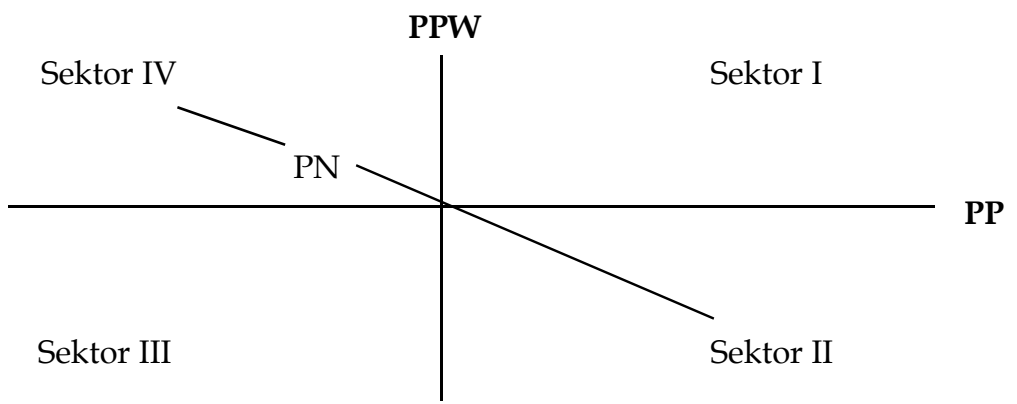

Gambar 2. Matriks Profil Pertumbuhan

Sumber : Budiharsono 2001 
e. Garis yang memotong kuadran II dan IV melalui sumbu yang membentuk sudut 450. garis tersebut merupakan nilai $\mathrm{PN}=0$, sehingga bagian atas tersebut merupakan PN positif (Pnij $\geq 0$ ) sehingga menunjukkan sektor-sektor yang progresif. Sebaliknya di bawah garis tersebut berarti menunjukkan sektorsektor yang lambat $(\mathrm{PN} \leq 0)$.

\section{Perumusan Strategi}

Analisis SWOT. Analisis ini dilakukan dengan merujuk kepada kekuatan pengendali internal (kekuatan dan kelemahan) dan eksternal (peluang dan ancaman) yang diperoleh dari studi pustaka dan informasi yang diperoleh dari instansi terkait dan pelaku usaha peternakan melalui langkahlangkah sebagai berikut :

a. Evaluasi faktor internal (Internal Faktor Evaluation / IFE)

Langkah kerja dalam penentuan faktor internal dan pembobotan adalah dengan membuat daftar kekuatan dan kelemahan, kemudian setiap kekuatan dan kelemahan diberi bobot (dari tidak penting $>0,0$ sampai dengan sangat penting $=1,0$ ) sehingga total bobot adalah 1,0 selanjutnya berikan rating $1 \mathrm{~s} / \mathrm{d} 4$ pada setiap kekuatan dan kelemahan ( $1=$ kelemahan utama, 2 = kelemahan kecil, 3 = kekuatan kecil, 4 = kekuatan utama), selanjutnya menentukan weight score dengan mengalikan bobot dengan rating (David, 2006).

b. Evaluasi Faktor Eksternal (External Faktor Evaluation / EFE)

Langkah kerja dalam penentuan faktor eksternal dan pembobotan adalah dengan daftar peluang dan ancaman, kemudian setiap peluang dan ancaman diberi bobot (dari tidak penting $>0,0$ sampai dengan sangat penting $=1,0$ ) sehingga total bobot adalah 1,0 selanjutnya berikan rating $1 \mathrm{~s} / \mathrm{d}$ 4 pada setiap peluang dan ancaman $(1=$ jawaban tidak baik/kurang, 2 = agak baik, 3 = baik, 4 = sangat baik), selanjutnya menentukan weight score dengan mengalikan bobot dengan rating (David, 2006).

Quantitative Strategic Planning Matriks (QSPM). Tahap terakhir dari formualsi strategi yaitu tahap pengambilan keputusan. Analisis yang digunakan pada tahap ini adalah matriks QSPM. David (2006) menyatakan bahwa QSPM adalah alat yang memungkinkan penyusun strategi untuk mengevaluasi alternatif strategi secara objektif, berdasarkan faktor keberhasilan kunci internal dan eksternal yang telah diidentifikasi sebelumnya.

Langkah-langkah yang dilakukan dalam penyusunan strategi terpilih melalui QSPM adalah sebagai berikut (David, 2006) :

1. Mendaftarkan peluang/ancaman (faktor eksternal) dan kekuatan/kelemahan (faktor internal) ke dalam matriks QSPM.

\begin{tabular}{|c|c|c|}
\hline & Kekuatan & Kelemahan \\
\hline & $\begin{array}{l}\qquad \text { (Strengths }-S) \\
\text { Daftar kekuatan dari faktor } \\
\text { internal }\end{array}$ & $\begin{array}{l}\quad(\text { Weaknesses }-W) \\
\text { Daftar kelemahan dari faktor } \\
\text { internal }\end{array}$ \\
\hline $\begin{array}{c}\text { Peluang } \\
(\text { Opportunities }-O) \\
\text { Daftar peluang dari faktor } \\
\text { eksternal }\end{array}$ & $\begin{array}{l}\text { Strategi SO } \\
\text { Gunakan kekuatan untuk } \\
\text { memanfaatkan peluang } \\
\text { dalam mengambil keputusan }\end{array}$ & $\begin{array}{l}\text { Strategi WO } \\
\text { Gunakan keuntungan/ } \\
\text { peluang untuk mengatasi } \\
\text { kelemahan yang dimiliki }\end{array}$ \\
\hline $\begin{array}{c}\text { Ancaman } \\
(\text { Threats }-T) \\
\text { Daftar ancaman dari faktor } \\
\text { eksternal }\end{array}$ & $\begin{array}{l}\text { Strategi ST } \\
\text { Gunakan kekuatan yang } \\
\text { dimiliki untuk menghindari } \\
\text { ancaman }\end{array}$ & $\begin{array}{c}\text { Strategi WT } \\
\text { Meminimalkan kelemahan } \\
\text { dan menghindari ancaman }\end{array}$ \\
\hline
\end{tabular}

Gambar 3. Matriks SWOT

Sumber : David, 2006 
2. Memberikan bobot untuk setiap faktor sukses kritis eksternal dan internal

3. Memeriksa/mencocokkan matrik dan mengidentifikasi strategi alternatif yang harus dipertimbangkan untuk diimplementasikan

4. Menetapkan skor kemenarikan relatif (Attractiveness Score/ AS) untuk masingmasing stategi alternatif yang terpilih yaitu 1 = tidak menarik, 2 = agak menarik, $3=$ menarik, dan $4=$ sangat menarik.

5. Menghitung Total Attractiveness Score (TAS) yang diperoleh dengan menjumlah hasil perkalian bobot dengan AS dalam setiap baris.

6. Menghitung jumlah Total Attractiveness Score dengan cara menjumlahkan semua TAS pada setiap kolom QSPM. Nilai TAS yang tertinggi menunjukkan bahwa strategi tersebut yang paling baik atau tepat untuk diimplementasikan.

Untuk penentuan bobot, rating dan Attractiveness Score pada masing-masing kriteria digunakan teknik Delphi yaitu dengan meminta pendapat responden yang dianggap ahli dan mengetahui tentang seluk beluk pengembangan peternakan di Kabupaten Agam Sumatera Barat.

\section{HASIL DAN PEMBAHASAN KONDISI GEOGRAFIS}

Kabupaten Agam merupakan salah satu kabupaten yang memiliki wilayah yang cukup luas dibandingkan dengan kabupaten atau kota lainnya di Sumatera Barat dengan luas wilayah 2.232,3 km2, terletak pada 00001'43"-00028'43" Lintang Selatan dan 99046'39'-100032'50' Bujur Timur. Ibu kota Kabupaten Agam adalah Lubuk Basung dengan jarak sekitar 114 km dari Kota Padang dan dapat ditempuh melalui jalur darat dengan jarak tempuh sekitar 3 jam perjalanan.

Berbatasan sebelah utara dengan Kabupaten Pasaman dan Kabupaten Pasaman Barat, sebelah timur dengan Kabupaten Lima Puluh Kota, sebelah selatan dengan Kabupaten Padang Pariaman dan Kabupaten
Tanah Datar dan sebelah barat dengan Samudera Indonesia. Kabupaten Agam terdiri dari 16 kecamatan dan 82 Nagari atau Desa dengan kecamatan terluas adalah Kecamatan Palembayan dengan luas wilayah mencapai $349,81 \mathrm{~km} 2$ atau sekitar 15,67 persen dari luas daerah.

Kabupaten Agam terletak di daerah tropis dengan suhu rata-rata di dataran rendah mencapai $25-33{ }^{\circ} \mathrm{C}$ dan suhu di dataran tinggi mencapai 20-29 ${ }^{\circ} \mathrm{C}$. Kondisi lahan yang terdapat pada wilayah ini merupakan perbukitan/pegunungan dan pesisir serta kawasan lindung. Basis ekonomi adalah pertanian yang terdiri dari perkebunan, pertanian lahan kering, lahan basah, hortikultura dan peternakan dengan kondisi iklim yang mendukung sepanjang tahun, serta perikanan. Adanya kondisi geografis Kabupaten Agam yang beraneka ragam, mulai dari pegunungan sampai pada pesisir pantai sangat mempengaruhi keragaman populasi ternak.

Daerah Kabupaten Agam sangat cocok sebagai lahan sektor pertanian termasuk didalamnya subsektor peternakan karena mempunyai penyinaran yang cukup sepanjang tahun serta curah hujan yang cukup tinggi. Penyinaran rata-rata selama tahun 2012 mencapai 3,96 persen dengan curah hujan 3.031,9 milimeter.

\section{KONDISI DEMOGRAFI}

Secara umum jumlah penduduk Kabupaten Agam pada pertengahan tahun 2013 adalah 466.978 jiwa. Perkembangan jumlah penduduk menunjukkan perkembangan yang positif dengan laju pertumbuhan penduduk 0,93 persen per tahun. Laju pertumbuhan penduduk di bawah 1 persen dinilai tidak terlalu tinggi. Dengan laju pertumbuhan penduduk tersebut diperkirakan jumlah penduduk akan bertambah menjadi dua kali lipat pada tahun 2085. Pertumbuhan jumlah penduduk yang cukup besar tersebut tentu saja harus diikuti oleh tingkat pertumbuhan ekonomi yang tinggi 
agar tingkat kesejahteraan masyarakat secara umum dapat meningkat pula.

Berdasarkan hasil Suseda tahun 2012 penduduk usia 15 tahun ke atas yang merupakan angkatan kerja yaitu 223.404 jiwa yang terbagi dalam dua yaitu yang bekerja sebanyak 215.123 jiwa dan yang berstatus pengangguran yaitu sebanyak 8.281 jiwa Angkatan kerja yang bergerak di bidang pertanian 41,74 persen, industri 15,55 persen, perdagangan 17,98 persen, jasa kemasyarakatan 11,73 persen, dan lainnya meliputi pertambangan dan penggalian, listrik, gas dan air, bangunan, angkutan, pergudangan dan komunikasi, keuangan, asuransi, persewaan dan jasa perusahaan mencapai 13,00 persen.

\section{PERKEMBANGAN PRODUK DOMESTIK REGIONAL BRUTO (PDRB) KABUPATEN AGAM}

Perkembangan PDRB Kabupaten Agam dari tahun 2009 hingga 2013 secara umum terus mengalami peningkatan. Pertumbuhan ekonomi Kabupaten Agam dari tahun 2009 hingga tahun 2012 bahkan mengalami percepatan. Pada tahun 2011 misalnya pertumbuhan ekonomi Kabupaten Agam adalah sebesar 5,94 persen, lebih cepat dibandingkan pertumbuhan ekonomi yang terjadi di tahun 2010 yaitu sekitar 5,66 persen. Puncaknya pada tahun 2012 pertumbuhan ekonomi kembali mengalami percepatan menjadi 6,79 persen.

Pada tahun 2013, tingkat pertumbuhan ekonomi di Kabupaten Agam tetap tumbuh, meskipun sedikit melambat menjadi 6,36 persen. Perlambatan tingkat pertumbuhan ekonomi di Kabupaten Agam juga seiring dengan perlambatan ekonomi yang terjadi di Provinsi Sumatera Barat dan di Indonesia Pada tingkat regional Sumatera Barat tingkat pertumbuhan ekonomi mengalami perlambatan dari 6,35 persen di tahun 2012 menjadi 6,18 persen di tahun 2013.

\section{STRUKTUR PEREKONOMIAN KABUPATEN AGAM}

Struktur perekonomian yang terjadi di suatu wilayah menunjukkan besar kecilnya pengaruh sektor perekonomian tertentu terhadap pembentukan PDRB di suatu wilayah. Selama tahun 2013 tidak terjadi perubahan struktur perekonomian yang mencolok dibandingkan dengan tahun-tahun sebelumnya. Sektor pertanian masih merupakan sektor dengan kontribusi terbesar di Kabupaten Agam. Meskipun dari tahun ke tahun terlihat kecenderungan penurunan distribusi, namun tidak begitu signifikan. Kontribusi sektor pertanian pada tahun 2013 adalah 39,31 persen, sedangkan di tahun 2012 adalah sekitar 39,72 persen.

\section{PERAN SUBSEKTOR PETERNAKAN}

\section{Potensi Subsektor Peternakan}

Kondisi Kabupaten Agam yang strategis di Provinsi Sumatera Barat menjadi keunggulan dalam pengembangan peternakan. Hal ini mempermudah pemasaran hasilhasil peternakan. Lahan yang subur membuat ketersediaan hijauan untuk pakan tersedia melimpah. Keadaan tersebut semakin meyakinkan bahwa peternakan di Kabupaten Agam memiliki potensi yang bagus serta dapat menjadi peluang investasi.

Secara umum sektor peternakan mengalami perkembangan yang berfluktuatif setiap tahunnya baik jumlah populasi ternak, produksi daging, susu dan telur. Namun sarana fisik peternakan tidak mengalami perkembangan bahkan cenderung tidak berubah. Populasi sapi potong pada tahun 2013 adalah sebanyak 33.831 ekor, sapi perah 115 ekor, kerbau 19.193 ekor, kuda 204 ekor, kambing 12.631, ayam petelur 185.770 ekor, ayam pedaging 147.901 ekor, ayam kampung 314.292 ekor, itik sebanyak 100.452 ekor dan puyuh 51.705 ekor. 
Penduduk yang memiliki ternak untuk dijual atau diusahakan secara komersial cukup banyak. Pada tahun 2013 jumlah rumah tangga ternak sapi potong mencapai 12.280, sapi perah sebanyak 98, kerbau sebanyak 8.111, kambing sebanyak 1.895, ayam ras pedaging sebanyak 116, ayam ras petelur sebanyak 34, itik sebanyak 2.657, kuda sebanyak 20, ayam lokal 6.267 dan lainnya (angsa, kalkun, burung merpati, burung puyuh, kelinci) 278 rumah tangga.

\section{Analisis Peran Subsektor Peternakan Kabupaten Agam}

Sebelum melakukan analisis LQ untuk sektor pertanian khususnya subsektor peternakan, terlebih dahulu dilakukan analisis LQ untuk masing-masing sektor ekonomi di Kabupaten Agam sebagai gambaran umum dengan pembanding Propinsi Sumatera Barat. Tahun 2012-2013 menunjukkan bahwa terdapat 5 sektor prekonomian yang menjadi basis yaitu sektor pertanian; bangunan; perdagangan, hotel dan restoran; keuangan, persewaan dan jasa perusahaan; dan sektor jasa-jasa. Dalam waktu rentang dua tahun sektor pertanian memiliki kedudukan sangat kuat dalam basis kabupaten Agam dengan nilai LQ masingmasing 1,64 dan 1,65. Ini berarti sektor pertanian memiliki keunggulan nilai kontribusi dalam perbandingan antar wilayah di tingkat Provinsi Sumatera Barat. Hal ini selaras dengan kontribusi sektor pertanian yang mencapai 39,31 persen.

\section{Analisis LQ Subsektor Peternakan}

Analisis LQ digunakan untuk menentukan basis subsektor peternakan diantara subsektor pertanian lainnya. Dari tahun 2011 sampai tahun 2013 subsektor peternakan menempati urutan ketiga setelah subsektor perkebunan dan sektor tanaman bahan makanan. Nilai LQ subsektor peternakan adalah 1,43, 1.,47 dan 1,46. Dengan demikian subsektor peternakan termasuk subsektor yang sangat penting peranannya dalam perekonomian wilayah
Kabupaten Agam dan layak untuk dikembangkan. Subsektor peternakan merupakan salah satu primadona komoditi perdagangan di Kabupaten Agam diantara lain sapi potong, sapi perah, ayam petelur, ayam pedaging, kerbau, kuda, itik dan kambing serta hasil olahannya.

\section{Surplus Pendapatan Subsektor Peternakan}

Besarnya surplus pendapatan subsektor peternakan dipengaruhi oleh pola permintaan nilai semua wilayah provinsi dan sistem perekonomian tertutup. Hasil analisis menunjukkan bahwa sektor basis menghasilkan surplus pendapatan yang positif sedangkan untuk komoditi non basis menghasilkan surplus pendapatan yang negative. Subsektor peternakan Kabupaten Agam mengalami surplus pendapatan yaitu pada tahun 2012 adalah sebesar Rp 3.369,09 (juta) dan Rp 3.467,44 (juta) pada tahun 2013. Dengan adanya surplus pendapatan yang cukup tinggi maka Kabupaten Agam dapat memenuhi kebutuhan masyarakat setempat juga masyarakat di kabupaten lainnya, sehingga memberikan keuntungan bagi kabupaten untuk membeli komoditi non basis guna memenuhi kebutuhan wilayahnya.

Jadi, surplus pendapatan subsektor peternakan yang cukup besar dapat dimanfaatkan untuk membeli komoditi nonbasis yang kurang memenuhi kebutuhan masyarakat. Ditingkat Kecamatan yang memiliki nilai surplus tertinggi adalah kecamatan tilatang kamang, baso dan lubuk basung. Surplus Pendapatan defisit terbesar berada di Kecamatan Ampek Angkek dan Palembayan.

\section{Kuosien Lokalisasi (Loi) Subsektor Peternakan}

Kousien lokalisasi yang mendekati nilai satu maka produksi peternakan lebih memusat dan beraglomerasi pada satu wilayah. Sedangkan nilai kuosien lokalisasi bila mendekati nol maka komoditi tersebut menyebar disetiap wilayah. Nilai Kuosien lokalisasi subsektor peternakan Kabupaten 
Agam ditingkat Provinsi Sumatera Barat adalah sebesar 0,01 .

\section{Analisis Shift Share}

Kontribusi sektor perekonomian di Kabupaten Agam maupun Propinsi Sumatera Barat telah mengalami peningkatan pada era otonomi daerah tahun 2009-2013, maka tiap sektor ekonomi akan memiliki rasio yang berbeda-beda. Rasio sektor perekonomian di Kabupaten Agam dan Propinsi Sumatera Barat disajikan dalam bentuk nilai $\mathrm{Ra}, \mathrm{Ri}$, dan ri. Nilai Ra didasarkan pada perhitungan selisih antara PDRB total propinsi Sumatera Barat tahun 2013 dengan total Propinsi Sumatera Barat tahun 2009, sehingga nilai Ra adalah yang didapat tiap sektor di seluruh kabupaten/kota yang ada ada di Propinsi Sumatera Barat memiliki nilai yang sama. Nilai Ra adalah sebesar 27,90 persen. Hal ini menunjukkan bahwa pada tahun 2009-2013 pertumbuhan ekonomi Propinsi Sumatera Barat meningkat sebesar 27,90 persen.

Nilai Ri dihitung berdasarkan selisih antara PDRB Propinsi Sumatera Barat subsektor Peternakan pada tahun 2009 dengan PDRB Propinsi Sumatera Barat subsektor peternakan pada tahun 2009 dibagi dengan PDRB Propinsi Sumatera Barat subsektor peternakan pada tahun 2009. Sehingga nilai Ri pada subsektor peternakan di seluruh kabupaten/kota di Propinsi Sumatera Barat memiliki nilai yang sama besar. Nilai Ri subsektor peternakan adalah sebesar 17 persen. Hal ini berarti ada peningkatan kontribusi sektor peternakan sebesar 17 persen terhadap PDRB Sumatera Barat.

Nilai ri memiliki perhitungan yang berbeda dengan nilai $\mathrm{Ra}$ dan Ri. Adapun perhitungan nilai ri didasarkan pada selisih antara PDRB subsektor peternakan Kabupaten Agam tahun 2013 dibagi dengan PDRB subsektor peternakan tahun 2009 dibagi dengan PDRB subsektor peternakan tahun 2009. Nilai ri PDRB subsektor peternakan adalah sebesar 2 persen. Pengaruh pertumbuhan regional menjelaskan seberapa besar PDRB Kabupaten Agam meningkat bila jumlah PDRB Propinsi Sumatera Barat persektor bertambah dengan laju yang sama dengan pertumbuhan regional, sehingga persentase komponen regional sama dengan persentase laju pertumbuhan, yaitu sebesar 27,90 persen.

Subsektor peternakan mengalami penurunan kontribusi peternakan sebesar 10,72 persen atau sebesar 8.483,16 juta. Subsektor peternakan memiliki daya saing yang baik dibandingkan dengan sektor-sektor lain. Hal ini ditunjukkan dengan persentase pertumbuhan pangsa wilayah mengalami peningkatan sebesar 2,33. Profil pertumbuhan sektor perekonomian digunakan untuk mengevaluasi pertumbuhan sektor peternakan dengan cara mengekspresikan persen perubahan PP dan PPW. Persentase PP pada sumbu absis dan PPW pada sumbu sebagai ordinat.

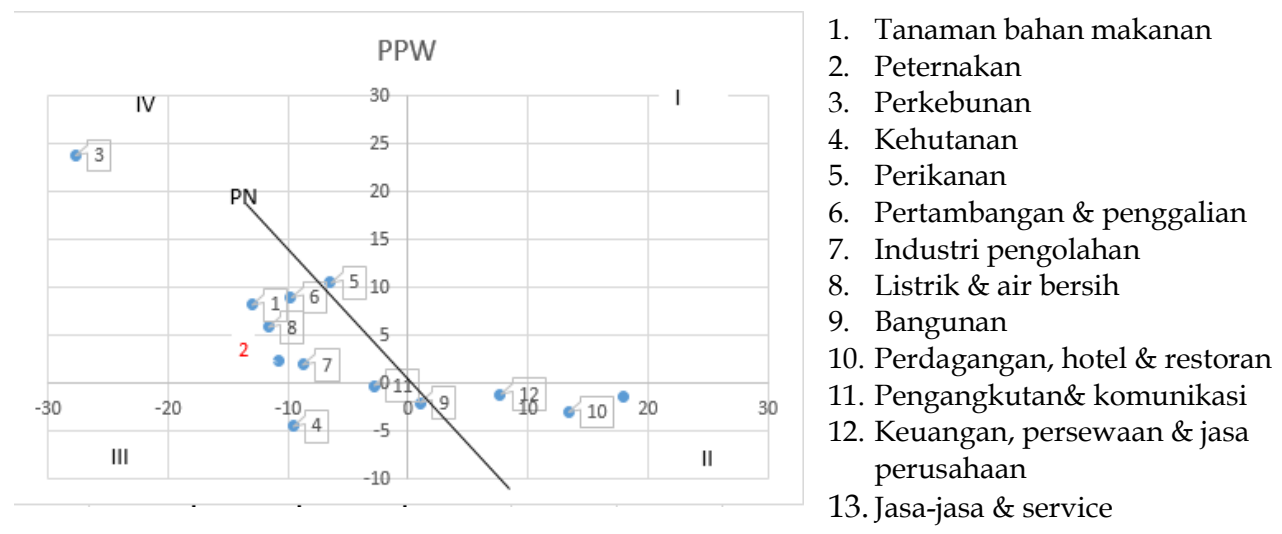

Gambar 4. Profil Pertumbuhan Peternakan Tahun 2009-2013 
Gambar di atas menunjukkan posisi peternakan berada pada Kuadran IV yang berarti pertumbuhan sektor peternakan di Kabupaten Agam mengalami pertumbuahn negarif/lambat tetapi memiliki daya saing yang baik. Sehingga nilai pergeseran bersihnya mengalami pertumbuhan negatif sebesar 8,39 persen.

\section{STRATEGI PENGEMBANGAN SUBSEKTOR PETERNAKAN}

Faktor Strategi Internal

\section{Faktor Kekuatan}

\section{a. Basis Ekonomi Peternakan}

Dengan menggunakan indikator pendapatan subsektor peternakan merupakan basis dengan nilai LQ ditingkat kabupaten sebesar 1,46 yang berarti peranan subsektor peternakan cukup penting bagi perekonomian Kabupaten Agam. Dengan nilai LQ sebesar itu Kabupaten Agam diharapkan dapat memenuhi kebutuhan hasil-hasil peternakan.

b. Potensi sumber daya alam

Dilihat dari aspek sumber daya alam seperti luas lahan serta potensi bahan pakan yang masih cukup tersedia dan potensial untuk dikelola bagi pengembangan peternakan. Sebagian lahan di Kabupaten Agam merupakan lahan yang subur. Sungai-sungai besar dan kecil terdapat cukup banyak sehingga dapat dimanfaatkan sebagai sumber pengairan bagi pertanian dan peternakan. Kabupaten Agam juga memiliki posisi yang strategis yaitu berada diantara jalur antara kabupaten dan ibukota Propinsi Sumatera Barat (Padang).

\section{c. Kemampuan memasarkan}

Keunggulan peternak di daerah ini dalam hal memasarkan produknya karena dekatnya jarak antar konsumen dengan produsen peternakan di Kabupaten Agam. Hal ini memberikan tingkat kepercayaan konsumen menjadi lebih baik kepada produsen daerah, alasan keamanan pangan, produk peternakan didaerah ini dapat langsung diketahui dan dinilai keamanannya oleh konsumen.

\section{d. Kebijakan Pemerintah}

Kebijakan adalah suatu keputusan yang memberikan arahan untuk memberi solusi terhadap permasalahan khusus yang berkembang dikalangan masyarakat. Kebijakan yang tepat akan memberikan dampak positif yang sesuai dengan yang diharapkan. Kebijakan tersebut tertuang di dalam Rencana Kerja Pemerintahan Daerah Propinsi Sumatera Barat Tahun 2014 yang bertujuan meningkatkan kualitas dan produktifitas sumberdaya manusia, ketahanan pangan.

\section{Faktor Kelemahan}

\section{a. Sumber Daya Manusia Peternak}

Salah satu inefisiensi dalam pengusahaan pengembangan peternakan adalah ketidakharmonisan antara pelaku dan pembina. Faktor ketidakharmonisan ini adalah rendahnya kualitas sumber daya manusia peternakan. Masih rendah dan terbatasnya kemampuan sumberdaya manusia akan menjadi hambatan dalam percepatan proses transfer teknologi dan pengetahuan kepada peternak dalam memanfaatkan dan mengembangkan sumberdaya yang tersedia. Dari sisi peternak diketahui sebagian besar peternak berpendidikan sekolah dasar bahkan ada yang tidak tamat pendidikan dasar.

\section{b. Penyebaran peternakan}

Lokasi peternakan menyebar diseluruh Kabupaten Agam. Hal ini diketahui dari nilai kousien lokalisasi subsektor peternakan di Kabupaten Agam bernilai 0,01. Bila nilai kousien lokalisasi kurang dari satu maka sektor tersebut menyebar merata. Lokasi peternakan yang menyebar ini terkait dengan sebagian besar usaha peternakan masih merupakan bersifat sampingan. Penyebaran peternakan ini membuat pengembangan peternakan menjadi lebih sulit karena membutuhkan biaya, waktu dan tenaga yang lebih 
besar untuk menjangkau lokasi usaha peternakan yang menyebar.

\section{c. Adopsi Teknologi}

Perkembangan informasi dan teknologi merupakan pendorong nilai tambah ekonomi yang juga dapat mendorong peningkatan daya saing bangsa Adopsi Teknologi yang rendah terjadi karena peternak secara umum kekurangan informasi atau masih berkaitan erat dengan terbatasnya kemampuan sumber daya peternak atau lembaga Pembina.

d. Ketersediaan Sarana Prasarana

Sarana Prasarana Peternakan di Kabupaten Agam belum tersedia secara memadai. Sarana peternakan pun tidak terdistribusi secara merata. Sarana peternakan kurang adalah pos kesehatan hewan, Rumah Potong Hewan yang masih tradisional dan belum terjaga kebersihannya, akses jalan ke sentra peternakan banyak yang rusak sehingga menyebabkan tambahan biaya bagi produsen.

\section{e. Kemampuan Modal Usaha}

Peternak kesulitan dalam mengembangkan usaha peternakannya karena memiliki keterbatasan modal. Usaha peternakan memerlukan modal yang cukup besar. Ketidakmampuan menyediakan modal ini terjadi karena masih rendahnya pendapatan penduduk. Selain itu akses modal petani terhadap fasilitas kredit cukup sulit karena persyaratan cukup banyak dan tingkat kepercayaan lembaga keuangan masih rendah terhadap sektor pertanian pada umumnya.

\section{f. Motivasi peternak}

Motivasi adalah kondisi dalam diri individu yang berhubungan dengan rangsangan sehingga mendorong seseorang bertindak untuk mencapai tujuan. Motivasi berperan dalam menentukan perkembangan dan keberhasilan suatu usaha. Hal ini terlihat dari belum meningkatnya sebagian besar sistem usaha sambilan/sampingan subsektor peternakan dan subsistem ke arah wawasan untuk menjadi pengusaha yang mandiri.

\section{Faktor Strategis Eksternal}

\section{Faktor Peluang}

\section{a. Potensi pasar}

Posisi Kabupaten Agam yang strategis yang terletak diantara ibu kota kabupaten/ kota dan ibu kota propinsi dapat menjadikan kota-kota tersebut menjadi peluang target pasar. Selain itu pertumbuhan penduduk kabupaten Agam yang cukup tinggi yaitu sebesar 0,93 persen per tahun menunjukkan perkembangan yang positif sedangkan rata-rata Sumatera Barat sebesar 1,33 persen pertahun sehingga menjadi peluang pasar baru.

\section{b. Ketersediaan kredit}

Tahun 2013 di Kabupaten Agam terdapat banyak cukup banyak bank dan koperasi simpan pinjam. Bank yang menyediakan kredit untuk usaha kecil atau usaha rakyat terdiri dari bank pemerintah dan swasta antara lain Bank Rakyat Indonesia, Bank Pembangunan Daerah dan BMT, hal ini dapat menjadi peluang untuk menyediakan modal bagi pengembangan peternakan di Kabu-paten Agam.

\section{c. Otonomi daerah}

Berlakunya otonomi daerah sejak tahun 1999 dengan lahirnya Undangundang No. 22 Tahun 1999 dan kemudian digantikan dengan Undang-undang Nomor 32 Tahun 2004 tentang pemerintahan daerah, memberikan kesempatan kepada masyarakat di daerah untuk mengatur diri sendiri melalui local self government dan melaksanakan pembangun-an sesuai prakarsa dan karakteristik daerah masing-masing.

\section{d. Pertumbuhan ekonomi}

Besarnya laju pertumbuhan ekonomi dapat dilihat berdasarkan kenaikan PDRB setiap tahunnya. Pertumbuhan ekonomi Kabupaten Agam. Laju pertumbuhan ekonomi agam pada tahun 2014 meningkat menjadi 6,7 dari 6,13 pada tahun 2013 dan diestimasikan meningkat menjadi 7,66 pada tahun 2017. Pertumbuhan ekonomi 
Sumatera Barat mengalami peningkatan sebesar yaitu dari 5,93 persen tahun 2010 menjadi 6,88 persen pada tahun 2013 dengan semakin baiknya pertumbuhan ekonomi tersebut maka akan meningkatkan daya beli masyara-kat, dengan demikian permintaan komoditi peternakan dalam rangka pemenuhan kebutuhan protein hewani masyarakat akan semakin baik.

e. Tuntutan keamanan produk (ASUH)

Selain tuntutan kuantitas terhadap ke-butuhan pokok produk peternakan, saat ini masyarakat luas telah mulai sadar akan pentingnya keamanan pangan yaitu produk hasil ternak yang aman, sehat, utuh dan halal. Pada saat ini standar kualitas ditentukan oleh konsumen, konsumen mempunyai kekuatan penuh untuk memilih produk yang sesuai dengan spesifikasi yang diinginkan. Tuntutan keamanan produk dapat menjadi peluang yang menambah nilai bagi produsen.

\section{Faktor Ancaman}

\section{a. Tingkat Inflasi}

Tingkat inflasi akibat tekanan krisis dan meningkatkan berbagai komoditas terutama pakan berdampak pada semua subsektor usaha peternakan. Inflasi yang tinggi akan berdampak pada stabilitas harga yang tidak menentu. Hal ini akan mengakibatkan peternak kesulitan membeli sarana produksi, sehingga mengancam kelangsungan usaha peternakan terutama bagi pengusaha ternak yang bermodal kecil.

\section{b. Kejadian penyakit ternak}

Kejadian penyakit ternak akan mempengaruhi tingkat keamanan dan produksi ternak. Isu penyakit antrax, avian influence, pemalsuan/kecurangan pada perlakuan daging/ternak sangat mempengaruhi kondisi peternakan di Sumatera Barat.

\section{c. Fluktuasi Harga}

Seperti halnya produk pertanian secara umum, harga produk peternakan juga sangat fluktuatif. Penyebab terjadinya fluktuasi harga produk peternakan adalah karena : pertama, pertumbuhan berat badan akan menemui titik optimum, sehingga konversi pakan akan semakin meningkat yang akan mengakibatkan tingkat keuntungan peternak semakin turun karena meningkatnya biaya pakan; kedua, produk peternakan seperti daging, telur, susu tidak dapat disimpan lama. Kedua hal ini menuntut peternak harus menjual hasil ternaknya walaupun harga saat itu murah. Disisi lain pada waktu-waktu tertentu seperti menghadapi hari-hari besar keagamaan (idul fitri, isra' mi'raj) harga produk peternakan dapat meningkat tinggi.

\section{d. Sosial budaya masyarakat}

Cukup banyak kasus pada pendirian usaha peternakan mengalami penolakan oleh masyarakat dilingkungan sekitar usaha peternakan di Kabupaten Agam. alasan utama penentangan ini adalah polusi yang ditimbulkan peternakan terutama polusi udara yang akan mengganggu mereka. Kasus pencurian pun akan menjadi ancaman bagi peternak.

\section{e. Pengaruh global}

Pengaruh global terutama ekonomi sangat mempengaruhi sektor peternakan baik langsung maupun tidak langsung. Pada saat ini pengaruh global yang dominan adalah krisis keuangan dan krisis ekonomi. Hal ini membuat perlambatan ekonomi dunia termasuk Indonesia. Tingkat konsumsi akan menurun dan ekspor pun ikut menurun. Sehingga pendapatan pemerintah mengalami penurunan, hal ini berpengaruh terhadap belanja pemerintah pusat dan daerah.

\section{Evaluasi Faktor-faktor Strategis}

\section{Evaluasi Faktor Internal}

Hasil perhitungan bobot dan rating dari faktor-faktor strategis internal yang mempengaruhi pengembangan subsektor peternakan di Kabupaten Agam. Elemen kekuatan terdiri dari empat faktor yaitu basis 
ekonomi, potensi sumber daya alam, kemampuan memasarkan dan Kebijakan pemerintah. Nilai bobot masing-masing faktor tersebut adalah 0,095; 0,102; 0,095; dan 0,095. Kelemahan kecil pada pengembangan peternakan di Kabupaten Agam adalah potensi sumber daya alam dengan nilai bobot 0,102 . Sedangkan faktor lain merupakan kelemahan utama.

\section{Evaluasi Faktor Eksternal}

Elemen peluang terdiri dari lima faktor yaitu potensi daerah, otonomi daerah pertumbuhan ekonomi, tuntutan keamanan produk dan ketersediaan kredit, masingmasing bobot faktor peluang tersebut adalah
0,085, 0,094, 0,100, 0,109 dan 0,100. Peluang yang dapat direspon dengan baik dalam pengembangan peternakan adalah potensi daerah. Hal ini berarti potensi daerah bila digali lebih lanjut akan menunjang keberhasilan pengembangan subsektor peternakan.

\section{Rekomendasi Prioritas Strategi}

Alternatif strategi yang didapatkan dari matrik SWOT dianalisis menggunakan QSPM untuk menetapkan strategi prioritas. Jumlah nilai tertinggi berarti menunjukkan bahwa strategi tersebut lebih menarik dilaksanakan dibanding strategi lain.

\section{Analisis SWOT}

\begin{tabular}{|c|c|c|}
\hline & $\begin{array}{l}\quad \text { KEKUATAN (S) } \\
\text { S1 Basis peternakan } \\
\text { S2Potensi Sumberdaya Alam } \\
\text { S3 Kemampuan memasarkan } \\
\text { S4 Kebijakan Pemerintah }\end{array}$ & $\begin{array}{l}\text { KELEMAHAN (W) } \\
\text { W1 Sumberdaya Manusia Peternak } \\
\text { W2 Penyebaran peternakan } \\
\text { W3 Adopsi Tekonologi } \\
\text { W4 Kemampuan Modal Usaha } \\
\text { W5 Ketersediaan Sarana dan } \\
\quad \text { Prasarana } \\
\text { W6 motivasi peternak }\end{array}$ \\
\hline $\begin{array}{l}\quad \text { PELUANG }(\mathbf{O}) \\
\text { O1 Potensi Pasar } \\
\text { O2 Ketersediaan kredit } \\
\text { O3 Otonomi Daerah } \\
\text { O4 Pertumbuhan ekonomi } \\
\text { O5 Tuntutan Keamanan } \\
\text { Produk }\end{array}$ & $\begin{array}{l}\text { STRATEGI S-O } \\
\text { 1. Pengembangan serta } \\
\text { pembinaan di setiap wilayah } \\
\text { berdasarkan potensi yang ada } \\
(\mathrm{S} 1, \mathrm{~S} 2, \mathrm{O} 1, \mathrm{O} 3)\end{array}$ & $\begin{array}{l}\text { STRATEGI W-O } \\
\text { 2. Pembinaan, penerapan dan } \\
\text { pengembangan teknologi yang } \\
\text { tepat guna }(\mathrm{O} 5, \mathrm{O} 3, \mathrm{O} 4, \mathrm{~W} 2, \mathrm{~W} 3 \\
\text { 3. Meningkatkan pembinaan dan } \\
\text { pengembangan SDM Peternak } \\
\text { (O1, O5, W1, W2, W3, W6) }\end{array}$ \\
\hline $\begin{array}{l}\quad \text { ANCAMAN (T) } \\
\text { T1 Tingkat Inflasi } \\
\text { T2 Kejadian penyakit ternak } \\
\text { T3 Fluktuasi Harga } \\
\text { T4 Sosial Budaya Masyarakat } \\
\text { T5 Pengaruh Global }\end{array}$ & $\begin{array}{l}\text { STRATEGI S-T } \\
\text { 4.Pengoptimalan dalam } \\
\text { pengamanan sumberdaya } \\
\text { lokal yang ada (T4, T5, S1, S2, } \\
\text { S3) }\end{array}$ & $\begin{array}{l}\text { STRATEGI W-T } \\
\text { 5. Membentuk dan } \\
\text { mengembangkan pola kerja } \\
\text { sama/bermitra yang lebih luas } \\
\text { dan saling menguntungkan (T2, } \\
\text { T4, T5, W1, W2, W4, W5) } \\
\text { 6. Melakukan pemeriksaan } \\
\text { kesehatan ternak secara } \\
\text { berkelanjutan dan pencegahan } \\
\text { penyakit hewan (T2, W1, W2, T4) }\end{array}$ \\
\hline
\end{tabular}

Gambar 5. Matrik SWOT Pengembangan Subsektor Peternakan 
Tabel 3. Alternatif Strategis Pengembangan Subsektor Peternakan di Kabupaten Agam

\begin{tabular}{|l|c|c|}
\hline \multicolumn{1}{|c|}{ Alternatif Strategi } & TAS & Rangking \\
\hline $\begin{array}{l}\text { 1. Pengembangan subsektor peternakan serta pembinaan } \\
\text { di setiap wilayah berdasarkan potensi yang ada }\end{array}$ & 6,278 & I \\
$\begin{array}{l}\text { 2. Meningkatkan pembinaan dan pengembangan sumber } \\
\text { daya manusia peternak }\end{array}$ & 5,773 & II \\
\hline $\begin{array}{l}\text { 3. Membentuk dan mengembangkan pola kerja sama/ } \\
\text { bermitra yang lebih luas dan saling menguntungkan }\end{array}$ & 5,618 & III \\
$\begin{array}{l}\text { 4. Melakukan pemeriksaan kesehatan ternak secara } \\
\text { berkelanjutan dan pencegahan penyakit hewan }\end{array}$ & 5,406 & IV \\
\hline $\begin{array}{l}\text { 5. Pembinaan, penerapan dan pengembangan teknologi } \\
\text { yang tepat guna }\end{array}$ & 5,330 & V \\
\hline $\begin{array}{l}\text { 6. Pengoptimalan dalam pengamanan sumberdaya lokal } \\
\text { yang ada }\end{array}$ & 4,982 & VI \\
\hline Sumber: data olahan & &
\end{tabular}

Berdasarkan hasil analisis QSPM seperti pada Tabel 3 di atas, terlihat bahwa strategi yang memiliki total daya tarik tertinggi adalah strategi pengembangan subsektor peternakan serta pembinaan dilakukan setiap wilayah berdasarkan potensi yang ada $(6,278)$. Hasil prioritas strategi alternatif ini dianggap pakar paling penting untuk dilakukan. Hal ini menunjukkan bahwa strategi ini sangat cocok dilakukan untuk meningkatkan peran subsektor peternakan dalam pembangunan perekonomian di wilayah Kabupaten Agam.

Pemilihan strategi pengembangan subsektor peternakan serta pembinaan di setiap wilayah karena selama ini peternakan yang ada masih bersifat sampingan dan sistem pemeliharaan yang tradisional yang bersifat subsistem. Secara umum peternakan di Kabupaten Agam masih didominasi skala kecil sehingga keuntungan yang diterima peternak pun masih tergolong kecil. Dalam rangka meningkatkan pendapatan dalam usaha peternakan maka perlu dilakukan strategi pengembangan dan pembinaan subsektor peternakan di setiap wilayah berdasarkan potensi yang ada. Sedangkan strategi dengan prioritas kedua, ketiga, keempat dan kelima, menunjukkan strategi pengembangan subsektor peternakan secara bertahap. Pada strategi ke enam merupakan strategi yang dilakukan apabila memungkinkan kondisi peternakan di daerah tersebut sudah sangat lemah.

\section{KESIMPULAN DAN SARAN}

\section{KESIMPULAN}

1. Subsektor peternakan berpotensi besar untuk dikembangkan. Dilihat dari tiga tahun terakhir ini hasil analisis LQ subsektor peternakan di Kabupaten Agam sebesar 1.43 (2011) , 1.47 (2012) dan 1.46 (2013). Subsektor peternakan menjadi basis ekonomi dan berperan besar bagi pembangunan Kabupaten Agam karena memiliki surplus pendapatan yang cukup besar yaitu Rp 3.369,09 juta (2012) dan Rp $3.467,44$ juta (2013) seiring itu subsektor peternakan memiliki pola menyebar meskipun laju pertumbuhannya negatif/lambat tetapi memiliki daya saing yang baik.

2. Dari hasil perumusan strategi dengan analisis faktor internal dan eksternal, alternatif strategi dari matriks SWOT menggunakan QSPM diperoleh strategi prioritas sebagai berikut pengembangan subsektor peternakan serta pembinaan di setiap wilayah berdasarkan potensi yang ada $(6,278)$, meningkatkan pembinaan SDM peternak (5.773), membentuk pola kerja sama yang luas dan saling menguntungkan (5.618), pemeriksaan kesehatan ternak dan pencegahan penyakit hewan (5.406), pengembangan teknologi (5.330) dan optimal dalam pengamanan sumber daya lokal (4.982). 


\section{SARAN}

1. Berdasarkan prioritas utama dari alternatif strategi terpilih maka saran yang dapat dilakukan bagi Pemerintah Kabupaten Agam yaitu meningkatkan jumlah tenaga penyuluhan peternakan agar menjangkau lebih banyak peternak yang ada di setiap wilayah yang ada di Kabupaten Agam serta dapat menarik investor untuk mengembangkan subsektor peternakan di Kabupaten Agam.

2. Untuk dapat mewujudkan sasaran yang telah ditetapkan maka diperlukan kerjasama secara terintegrasi antar semua pihak yang terkait dari hulu hingga ke hilir. Pihak tersebut meliputi peternak, stakeholder, pemerintah, perguruan tinggi, lembaga peneliti, dan seluruh pihak lain yang terkait.

\section{DAFTAR PUSTAKA}

[BPS] Badan Pusat Statistik Kabupaten Agam. 2014. PDRB Kabupaten Agam Tahun 2009-2013. Lubuk Basung: BPS Kabupaten Agam.

[BPS] Badan Pusat Statistik Propinsi Sumatera Barat. 2014. Sumbar dalam Angka Tahun 2013. Padang: BPS Propinsi Sumatera Barat.

Bahar, Zul Amry. 2006. Strategi Pengembangan Peternakan dalam Rangka Meningkatkan Peran Subsektor Peternakan di Kabupaten Bengkalis [Tesis]. Bogor: Sekolah Pasca Sarjana Institut Pertanian Bogor.

Basuki Tri A, Gayatri Utari. 2009. Penentu sektor unggulan dalam pembangunan daerah. Jurnal Ekonomi dan studi pembangunan. 10(1): 34-50.

Budiharsono, S. 2001. Teknik Pengembangan Wilayah Pesisir dan Lautan. Jakarta: Pradnya Paramita.

David, Fred R. 2006. Manajemen Strategis: Konsep edisi kesepuluh. Salemba empat. Jakarta.
Diao, Xinshen,Thurlow J. 2010. The Role of Agriculture in African Development. Journal World Development. $\mathrm{xx}(\mathrm{x})$ : $\mathrm{xxx}-\mathrm{xxx}$.

Herlinda, Susy. 2007. Arahan Penataan Kawasan Penebaran dan Pengembangan Peternakan Sapi Potong di Kabupaten Lima Puluh Kota [Tesis]. Bogor: Sekolah Pasca Sarjana Institut Pertanian Bogor.

Ilham, Nyak. 2007. Alternatif Kebijakan Peningkatan Pertumbuhan PDB Peternakan di Indonesia. Bogor: Pusat Analisis Sosial Ekonomi dan Kebijakan Pertanian. Analisis Kebijakan Pertanian. Volume 5.

Kementan. 2013. Laporan Data Kinerja Kementerian Pertanian tahun 20042012. Jakara.

Marimin. 2004. Teknik dan aplikasi pengambilan keputusan kriteria majemuk. Grasindo. Jakarta.

Saragih B. 1998. Agribisnis Berbasis Peternakan. Frans BM, editor. Bogor: Pusat Studi Pembangunan LP-IPB. 